Вісник Національного університету “Львівська політехніка”: журналістика

№ 1 (1), 2021

UDC 070.004:[738.05-070.00] - (138)

https://doi.org/10.23939/sjs2021.01.025

Yuliana Kazimova

Lviv Polytechnic National University, assistant of the department of journalism and mass communication kazimovauliana@gmail.com

\title{
RUBRICS AND FEATURES OF INFORMATION PRESENTATION IN THE INTERNET MEDIA "UKRAINSKYI TYZHDEN"”
}

(C) Kazimova Yu., 2021

The article describes the features of the selection of headings in the internet media of the "Ukrainskyi tyzhden". Today, for modern journalists, the issue of not only the diversity of rubrics in internet publications, but also the compliance of rubrics with the needs of readers is relevant. To do this, the article analyzes which rubrics journalists prefer in the first place. What names of headings do they choose. How they prepare materials for a specific heading.

Some journalists like to repeat the names of columns, like to take these names from other media. But it is not right to do like this. Each media must be unique.

It doesn't mean that journalists can not cover the same information. Of course, the information will always be the same, because all the media write about the same things, according to events. But no matter which information, because the main is how it is presented. First of all, it should be the most important information that people need. This should not be plagiarism from another publication. This must be a unique presentation of the material not in a short form. The material should be presented clearly and distinctly, at the same time, interestingly. Every journalist must remember that important skills that a modern journalist should possess are first and foremost literary ability, language and style of the author, the ability to express their thoughts and reveal the position of another, the ability to accurately and vividly tell about the event, to convey the fact, evaluate and explain.

Also it is necessary to notice that the internet media "Ukrainskyi tyzhden"" were taken to study the materials. "Ukrainskyi tyzhden"' has a special approach to the selection of headings. During this research we noticed that there are only five headings in this internet media, including: "Articles", "Columns", "Photo Report", "Magazine", "Press Releases". The brightest rubric is "Articles". It has many subheadings. One of the most interesting is "Pandemic". Also it is worth to notice that all materials from "Articles" rubric are suitable for the names of headings. Very good subheadings are "Politics" and "Economy", a good subheading also is "World".

Keys words: heading; subheading; features of Internet media materials.

Relevance of research. Today the most important thing for modern journalists is a question not only about different rubrics but also their relevance to the needs of readers. That's why in this article is analyzed, which rubrics (headings) journalists give attention first of all, which of them they prefer to take as name of main rubrics of modern Internet media. Also important question is how journalists prepare materials for some exactly heading.

Some of them love to repeat the names of rubrics of other internet media. But it's not good to do this. Every media must be unique. We don't speak here that journalist doesn't have right to show the same information which another media used. Because everything what happens every day - is very important 
and all of journalists must write about it. The important is not which information was written but how it was written. It can't be plagiatism from another media. It must be unique way of writing materials, not in short form. Such material must be written easy, exactly and interesting.

Objest of study - Internet media - "Ukrainskyi tyzhden"”. Subject of study - specific of rubrics and materials Internet media "Ukrainskyi tyzhden"".

The purpose of the work is to explore the diversity and specificity of the rubrics in the internet media "Ukrainskyi tyzhden"". The aim is to perform the following tasks: to study the methods of presenting information by journalists in internet media, to find out which titles journalists prefer today, to study headings on the example of internet media "Ukrainskyi tyzhden"" and compare these rubrics with the other. The novelty of the work - in the study of the latest materiasl under the headings of the internet media "Ukrainskyi tyzhden"". The following methods were used for the study: monitoring, synthesis and content analysis.

The main presentation of the material. The internet media "Ukrainskyi tyzhden"” has a special approach to the selection of headings. It is starting with the design of the interface of this media. In general, the interface of the media is white, only where are headings is red. Under the Ukrainian name of the internet media, there is smaller name - in translation to English language. I think that such colors are well and good chosen. It is also necessary to note that in order for modern journalism to meet the relevant requiremetns, it is necessary that only real professional journalists work in this field [2, p. 287]. There are only five headings in this internet media, including: "Articles", "Columns", "Photo Report", "Magazine", "Press Releases". In order to investigate whether the headings and names for them are well chosen, we need to consider each of them in details. So, the first column is "Articles". If at first it seemed that there were few headings, little, then after opening the heading "Articles", we saw that can see that there are a lot of subheadings, which explains the small number of headings. Thus, the subheadings of the rubric "Articles" are as follows: "All articles", "Politics", "Economy", "World", "Society", "Culture", "History", "Science", "Pandemic", "Elections-2020". In the subheadings "All articles" you can find the following interesting and relevant materials: "Risks and opportunities - what will bring 2021", "Andriy Pinchuk: Deinstitutionalization reform is a bad reform in terms of television pictures", "National Question", Resistance to Reforms and Diversity: Features of Politics in the South of Odesa Region, "Unnatural Selection. Who specifically gained power in the regional councils of Ukraine", etc. In the article "Risks and Opportunities" - what 2021 will bring, journalists report that past experience suggests that the forecast is too unpredictable in the current conditions, but reviewers of the world's largest media and think tanks offer their views on the risks, opportunities and trends of 2021. Of course, most risks, hopes and opportunities are associated with the pandemic which will continue next year. For example, The Atlantic Council identified the escalation of the coronavirus crisis as a number 1 risk next year. Analysts believe that the crisis may be exacerbated if the vaccination process is still slow, which is very possible. "Distribution of vaccines may face unexpected production and logistics problems, which in turn will delay the time when the majority of the population can receive vaccinations", - the Atlantic Council predicts. In addition, the fact that many people say they are not ready to be vaccinated may be affected. Thus, in the United States, $42 \%$ of the population say they will not do so. All this may reduce the chances of stopping the infection by the second half of 2021. Due to the pandemic, travel restrictions will probably last for a good half of 2021. Regarding the publication, namely an interview with Andriy Pinchuk: "Deinstitutionalization reform is a bad reform in terms of television picture", it is worth notice that one of the very successful questions was - how long have you been caring for deprived of care? Where did it all start for you? The answer was: "Behind the fence of the temple where I began to serve was an orphanage. This is a neighborhood that cannot be missed - we constantly went there, organized some trips, talked, helped. The first two children my wife and me took now lives on the same street as us and recently gave us 
a third granddaughter. And then the boys were almost teenagers, that is, in their most difficult age, but we established a certain relationship. At least that's how it seemed to us... Honestly, our first experience turned out to be very difficult and I'm not inclined to talk about such parenthood only positively. But life is different, and if you have already decided, you need to be ready for anything... Even financially. For example, you need to understand that with the arrival of children, you will definitely suffer losses in the family budget, because they will spoil different things, because they are not used to caring or appreciating something. I always tell young foster parents that they should set a certain limit, and if the loss of property does not exceed this limit every month, do not be nervous - because everything is fine, everything is going according to plan!".

The following materials were memorized in the rubric "Politics": "Deep Currents" and "Slippery Democracy". The article "Deep Currents" talks about how social trends will affect the development of the situation in the country in the coming years. Journalists are trying to find out how the political situation will develop in 2021, and even more so what the disposition will be in the run-up to the upcoming parliamentary and presidential elections - it is difficult, if not impossible, to predict. In the above mentioned article, journalists noted that during 2020, an irriated majority returned to Ukrainian politics the same one that deprived Petro Poroshenko of power last year. It is this irriated majority that will become an electoral reserve for all opposition forces - both those currently represented in parliament and those who will claim entry (or return) to the top league of Ukrainian politics. In addition, ideological polarization of the political process shoud be expected in the coming years. Most Ukrainian parties, both pro-Russian and patriotic, are by nature oligarchic projects (and often one-day projects), and they do not rule out the fact that there is an objective reality behind the ideological split. At the heart of this split is the struggle of two paradigms of Ukraine's existence: as an independent European state and as a quasi-state appendage of Russia. An article entitled "Slippery Democracy" states that the referendum of December 1, 1991 became the starting point for building the newest Ukrainian state. And - an iron argument in its favor. Because no one in the world from the moment when more than $90 \%$ of Ukrainians said "Yes" to an independent state had the right to doubt its legitimacy. But very little time has passed, and they are now trying to use the referendum tool to destroy this state. So far without success, but the process is progressing. In this article, journalists noted that the referendum is one of Putin's favorite pastimes. He has long realized the potential hidden behind this multifaceted word, and with great pleasure puts it into action wherever he can. So he succeeded before the referendum for the continuation of his control in Russia, the expansion of the territories and the strength of the influx into the suspects - and, obviously, for geopolitical cities in the whole world. Follow the Kremlin's creativity is known both on the canvas of Brexit, and at the stage of the Catalan referendum on the introduction of the Spanish. Obviously, it's the same way that the Kremlin is already richly destined to draw in Ukraine.

Under the heading "Economics", we can read the publication under the name "Budget with the word and the lenght". At the top of the statistics of the internet journalism, the Internet media "Ukrainskyi tyzhden" " is by no means the Supreme Council of the fifth convocation with 289 votes in favor, adopted a bill on the state budget for 2021 year. At the end of the past rock, the voices of the "servants" for the whole ice were drawn from the heads of Supreme Council (225+1 at 226 required). The naturalness of the final vote demonstrated the approach of the head estimate from the side of the traditional remaining hours of the SN parthners at the parliament.

However, the position of the Fund traditionally matched the deficit, which, among the first and other readings was reduced by UAH 23,7 billion.

Under the heading "World" worth paying attention to the material under the name "War of generations". In a whole of material, it is meant that the situation of the prototypes of the young generation and the older generation of politicians is deprived of one sign that is seen at the closest hour by the light. Pandemics may be a tendency to enlighten the apparent problems and radicalize protest moods, so that all too soon, if the super-stream is not possible, radicalism in politics. The nature of the middle of the young gerenation is victorious. And if in them there will be less chances of adopting their order of day on the 
political level, at the present time there will be "direct democracy". Among the most important categories of information, if look the rubric "Pandemic", which was published in the article under the name "Doctors, collective immunity and masks - look at the news about the medical news magazine about the coronavirus", - personnel, who are often referred to the group of patients of COVID-19, not representatives of other proffesions. In any case, the majority of powers have to enter the group of adolescent risk, and the stench is the one of the first to get vaccinated.

An article about weak immunity and coronavirus was also submitted under the heading of the bullet, in which media was informed, but The New England Hournal of Medicine describes a medical thriller. A 45-year-old person with ailments for antiphospholipid syndrome (APS), rarely autoimmune sickness is diadnosed in 5 people out of 100 thousand. An affiction is characterized by frequent affictions of blood clots through antiphospholiped antibodies.

Five months before the infection in the drug, due to the symptoms of a cold (if the coronavirus is diagnosed), the patient has a bleeding because of AFS. The man was prescribed a five-day course of medicine, after this he was discharged from the hospital five days later and did not need additional oxygen therapy. From day 6 to day 68 he was self-isolated at home, during which time he was hospitalized four times with APS -related symptoms. On day 72 he was again diagnosed with coronavirus. The man could not be infected anywhere so it is associated with an increase in viral load after the first time, when probably not all viral particles were destroyed by immunity and treatment. After a 10-day course of treatment the test became negative. On day 128 the coronavirus reappered. Until now the man had been receiving extra oxygen for some time due to complications from APS. After a new five day dose of treatment, PCR no longer showed the presence of the virus. 154 days after the first positive test and man died. So journalists written this in their article and this information is very important. People must know such information.

Also it is worth to notice that all materials from "Articles" rubric were analyzed December 2020. The materials are suitable for the names of headings. Very good subheadings are "Politics" and "Economy", a good subheading also is "World", and the most relevant is "Pandemic", as journalists of the "Ukrainskyi tyzhden" try timely and promptly submit the latest information under this important rubric, for people.

Is is also worth notice that all subheadings are also placed at the bottom of the page of this internet media. Other rubrics of this internet media should also be considered. Under the heading "Columns" you can see articles of the following topics: "Not to be worse", "It is time to uncork champagne", "Iran and Turan in modern geopolitics", "Solidarity is the best defense", "Show during the plague", "Vaccination living virus", "Gratitude of gratitude", "Personally formula" etc. In the rubric "Photo Report" there are materials with photos, among the following articles: "Day of Dignity and Freedom in Kyiv", "Empty chairs", "Ukrainian corporals are ready to guide the aircraft" etc. It is clear that under the heading "Journal" there are all issues of the magazine of the same name as this internet media. And in heading "Press Releases" journalists submit the following materials: "Installation of ventilation equipment in Kiev and the region", "Is hookah without nicotine really so safe?", "Covid-19" - a virus that has put the world in quarantine, "Top 5 gifts that will surprise your loved one" etc.

Also it must be noted that important skills that a modern journalist should possess are first and foremost literary ability, language and style of the author, the ability to express their thoughts and reveal the position of another, the ability to accurately and vividly tell about the event, to convey the fact, evaluate and explain [1, p. 383]. His professional competence is also determined by the level of social responsibility to society and the audience, the sense of social justice and the level of his objectivity. It is important that the information which is provided is true so that the virtual reality picture adequately reflects the reality [3, p. 321-324].

It should also be noted that in recent times adherence to norms of ethics is considered as the main component for a journalist, as a particular component of his skill. Given the ability of a person to journalism can not be judged without regard to its ethical qualities, which are no less important than qualification [4, p. 324 ].First, internet media "Ukrainskyi tyzhden" has a special approach to the selection of headings. 
Conclusions. Therefore, from the above material we can draw the following conclusions. There are only five headings in this internet media, including: "Articles", "Columns", "Photo Report", "Magazine", "Press Releases", but one of the heading contains many subheadings.

The brightest rubric is "Articles". It has many subheadings. One of the most interesting is "Pandemic". After all, under this subheading are articles that are most relevant to all people needs. As soon as new information about coronavirus disease appears, journalists immediately submit this information to this subheading.

In "Ukrainskyi tyzhden"” are also other subheadings: "All articles", "Politics", "Economy", "World", "Society", "Culture", "History", "Science", "Elections-2020". Journalists of the Internet media "Ukrainskyi tyzhden" "have created good names of rubrics, successfully came up with subheadings and their materials are always relevant, modern and up-to-date. This is evidenced by the daily and constant updating of this internet media with new and relevant materials.

\section{REFERENCES}

1. Kalmykov A. A., Kohanova L. A. Internet journalism: textbook. manual for university students studying in special. 021400 «Journalism». M. UNITI-DANA, 2005. 383 p.

2. Korkonosenko S. G. Fundamentals of Journalism: A Textbook for Universities. M., Aspect Press, 2001. $287 \mathrm{p}$.

3. Kotsarev O. O. Typology of Internet-media. Scientific notes of the Taurida National University. V. I. Vernadsky. Avg. Philology. 2006. T. 19, No. 5. P. 321-324.

4. Craig R. Internet journalism: the work of a journalist and editor in the new media. K., Kind of. House of Kyivo-Mohylians'ka Academy, 2007. 324 p.

Юліана Казімова

\section{РУБРИКИ ТА ОСОБЛИВОСТІ ПОДАННЯ ІНФОРМАЦІї У ІНТЕРНЕТ-ЗМІ «УКРАЇНСЬКИЙ ТИЖДЕНЬ»}

У статті досліджено особливості висвітлення журналістських матеріалів у Інтернет-ЗМІ «Украӥнський тиждень» та специфіку рубрик видання. Це питання актуальне сьогодні, оскільки деякі журналісти люблять повторювати назви рубрик, полюбляють брати ці назви 3 інших видань. Але так чинити неправильно. Кожне видання повинно бути унікальним.

Необхідно зазначити, що Інтернет-видання "Украйнський тиждень" відповідально підійшло до питання підбору рубрик. У цьому Інтернет-виданні лише п'ять рубрик, серед них такі: “Статті”, “Колонки”, “Фоторепортаж”, “Журнал”, “Прес-релізи”, проте одна із рубрик - “Статті” містить багато підрубрик.

Отже, серед підрубрик рубрики "Статті” є такі: “Усі статті”, “Політика", “Економіка", “Світ”, “Суспільство”, “Культура", “Історія”, "Наука", “Пандемія", “Вибори-2020”. Під підрубрикою "Усі статті" журналісти подають найбільш загальну інформацію, яка є важливою впродовж певного дня. Щодо підрубрик "Політика" та "Економіка", то під ними подана лише відібрана, актуальна інформація. Підрубрика "Світ" с не дуже великою, проте завдяки йй можна дізнатися найважливіші події, які відбуваються у світі. Найактуальнішою підрубрикою є “Пандемія”. Саме під цієї підрубрикою журналісти подають інформацію про кількість хворих на коронавірус, способи лікування цієї хвороби, а також постійно попереджають людей про те, що краще берегти здоров'я завчасно, аби уникнути зараження.

Матеріали у цьому Інтернет-виданні завжди подані професійно та оперативно. Їх цікаво читати, чому також сприяє й інтерфейс цього Інтернет-3МІ. Варто зазначити, що специфіка роботи журналістів вищезазначеного Інтернет-видання дає зрозуміти, що вони намагаються не висвітлювати однотипні новини, бути цікавими, писати матеріали лише на актуальні теми. У більшості випадків, інформація у різних ЗМІ однакова, адже від актуальних щоденних подій не втечеш. Проте навіть та сама інформація, яку подають усі 3МI, у Інтернет-виданні «Український тиждень» завжди подана оригінально та цікаво, аби читачі могли легко їі зрозуміти та правильно сприйняти.

Ключові слова: рубрика; підрубрика; особливості матеріалів Інтернет-ЗМІ. 